\section{UTMOST GOOD FAITH - UNINTENDED INJUSTICE?}

For over two hundred years a policy of insurance has been regarded as a contract of the utmost good faith. This principle is about to be modified. The Consumer Insurance (Disclosure and Representations) Bill received its second reading in the House of Lords on June 15, 2011 and will now be scrutinised by a Special Public Bill Committee. Clause 2 of the Bill amends the duty of utmost good faith in two respects as it applies pre-contractually to consumers: it abolishes the duty of disclosure and alters the remedies available to an insurer for misrepresentation.

Advocates of reform point to the harsh effects of the existing law. Take, for instance, the duty of disclosure. When purchasing a policy, a consumer must disclose all material facts to the insurer, regardless of whether or not the insurer asks relevant questions. A material fact is one which would have an effect, not necessarily decisive, on the mind of a prudent underwriter in assessing the risk. If an insurer is induced to enter into a contract by a nondisclosure it may on becoming aware of the true facts avoid the policy $a b$ initio and reject any claims (Pan Atlantic $v$ Pine Top [1995] 1 AC 501). This is so whether the consumer acted fraudulently, negligently or entirely innocently.

In Lambert v Co-operative Insurance Society Ltd [1975] 2 Lloyd's Rep 485, Mrs Lambert insured her jewellery under an all-risks policy for more than nine years. When the jewellery was lost, her claim was rejected on the grounds that she had not disclosed that her husband had been convicted of two offences of dishonesty. The omission was hardly surprising as the insurer had never asked Mrs Lambert about such matters. As MacKenna J said: "Mrs Lambert is unlikely to have thought that it was necessary to disclose the distressing fact of her husband's conviction when she was renewing the policy on her little store of jewellery. She is not an underwriter and has presumably no experience in these matters". Despite expressing sympathy with Mrs Lambert, the Court of Appeal was faced with clear law and felt obliged to find for the insurer.

What are the origins of this onerous rule of law? Insurance law students at St Mary's University College, Twickenham are advised to visit the parish church, where a black marble slab covers a family burial vault. Although the slab is badly damaged a familiar name is visible: "Under this marble in a vault lies buried the body of Charles Boehm, esq. who died January 26, 1769, aged 69 years". Charles Boehm was, of course, the defendant insurer in Carter v Boehm (1766) 1 Blackstone W 593, the landmark case in which Lord Mansfield delivered the first clearlyreported decision on the duty of disclosure. In 1759, during the Seven Years War, Roger Carter was employed by the East India Company as Deputy-Governor of Fort Marlborough, a lightly fortified trading post on the island of Sumatra. Those holding such appointments were expected to augment their remuneration by conducting business on their own account. Fearing attacks from the French and the native population, and wishing to protect his trading stock, Roger Carter sent a letter to England

\section{Articles}

Hello Mr Clips

3

Accession of the European Union to the European Convention on Human Rights

Institute News

Articles (cont'd)

Colonial copyright: an early case of globalisation

The coalition and constitutional reform

asking his brother, George Carter, to arrange insurance on his behalf. On March 29, 1760, the Comte d'Estaing, aided by Dutch pilots, sailed a warship and a frigate into the bay outside Fort Marlborough. Roger Carter and others fled into the interior of the island, but were later captured by the French and their possessions seized.

Oblivious to these developments, George Carter received his brother's letter and instructed a broker named Cawthorne to arrange insurance. The policy, retrospective to December 1, 1759, was underwritten by Charles Boehm, a well-known merchant in the City of London. However, when Roger Carter made a claim for $£ 10,000$ in respect of his lost trading stock, it was rejected by Boehm on the grounds that Carter had failed to disclose his fears of attack and the weaknesses of Fort Marlborough. In a classic judgment, Lord Mansfield said: "Insurance is a contract on speculation: the special facts usually lie in the knowledge of the insured only. The underwriter trusts to him, that he conceals nothing, so as to make him form a wrong estimate. If a concealment happens without any fraudulent intention by mistake of the principal or his agent, still the policy is void...". The law was subsequently codified in the Marine Insurance Act 1906, the relevant provisions of which have been held to be equally applicable to non-marine insurance.

Is it wise to interfere with such a well-established if potentially harsh rule of law? Perhaps a better question is whether the rule should ever have been applied to consumer insurances. In 1759 personal insurances were the preserve of the wealthy. The wide range of policies and sales channels available to all today did not exist. Would Lord Mansfield have regarded it as appropriate to impose a duty of disclosure on consumers of modern mass-market insurance policies? Five factors might have given him pause for thought:

\section{Relative expertise}

In Carter v Boehm, Lord Mansfield was settling the rules to be applied to business insurances, where parties have similar bargaining power and experience. In Georgian times the sharing of risk was commonplace in the City of London; a merchant might be an insurer for some transactions and an insured for others. Consequently it was not unreasonable to expect prospective insureds to 
understand what needed to be disclosed. Then as now commercial insureds looked for certainty and a pragmatic approach. Contrast this with the position of a modern consumer who will typically have no knowledge of insurance law and may expect and deserve an approach grounded in fairness.

\section{Absence of advice}

Roger Carter's policy was written as a custom contract agreed in a face-to-face transaction with the prospective insured advised by a broker. That is very different from consumer policies today where there is little opportunity to individually negotiate terms and sales are increasingly made over the internet or telephone without the involvement of a broker.

\section{Ease of communications}

In 1759, it might have taken a year or more for an enquiry to be sent by packet ship to Sumatra and for a reply to be received. There was no opportunity for a discourse with Roger Carter - writing insurance at such a distance would have been totally impracticable unless the prospective insured could be relied upon to disclose all relevant information. Nowadays questions can rapidly be posed and answered over the web, by telephone, email or fax or even by post.

\section{Inequality of knowledge}

Lord Mansfield suggested that "the special facts usually lie in the knowledge of the insured only" but nowadays insurers have access to a wide range of databases, research results and loss statistics. For example, 95 per cent of the household insurance market is covered by CUE, a system which records previous incidents and claims and will often prove more accurate than a consumer's memory. Motor insurers have founded their own research establishment at Thatcham. Life insurers employ actuaries to provide statistics on all aspects of mortality and morbidity - in 1759 the establishment of the first life insurer to underwrite business on scientific principles was still three years away. Of course some facts remain in the knowledge of the prospective insured alone, but if important these can and should be the subject of clear questions.

\section{Failure of reciprocity}

Lord Mansfield considered that the duty of disclosure was reciprocal. However, over subsequent years the obligations on a prospective insured appear to have become more onerous, whilst the duty of disclosure on insurers has proven to be limited to matters affecting the nature of the risk or the recoverability of a claim. Furthermore the sole remedy available for non-disclosure - avoidance of the contract - is valuable to insurers as it removes the liability to pay claims, but unattractive to consumers who would prefer damages to a mere return of premiums. Steyn J, as he then was, made a bold attempt to establish true reciprocity in a commercial case, Banque Keyser Ullmann SA v Skandia (UK) [1987] 2 WLR 1300, but was overturned on appeal.

It should also be noted that despite statements to the contrary in Wikipedia and, more surprisingly, at least one leading textbook, Lord Mansfield found in favour of Roger Carter. In doing so he recognised the severe impact of avoidance and warned that inappropriate reliance by an insurer on the duty of disclosure could itself amount to fraud.

Taking these factors together, one may reasonably doubt whether the duty of disclosure should have been applied to consumer insurances. Certainly industry and regulatory initiatives have long recognised that the duty should be modified or abandoned. In 1981, Mike Harris of Guardian Royal Exchange announced that the duty would no longer be relied upon by his company for general insurance. His explanation still rings true: "You cannot import into the way we handle bulk insurance products now the close contractual relationship derived from the time a ship or cargo owner dealt directly with an underwriter in a coffee house 300 years ago...". More recently, in 2005, the Financial Ombudsman Service issued guidance indicating it will not support insurers where they rely on the duty of disclosure. Rules issued by the Financial Services Authority recognise the duty but in the absence of fraud bar an insurer from rejecting a claim for non-disclosure where the consumer could not reasonably be expected to have disclosed the fact in question. After damaging publicity relating to rejected critical illness claims, insurers issued a code entitled Non-Disclosure and Treating Customers Fairly which seeks to mitigate the worst aspects of the law, though only in respect of life, critical illness and income protection insurance. However, these and other measures do not offer a complete answer to the ills of the law and the inconsistencies of approach and scope may cause confusion.

The Consumer Insurance (Disclosure and Representations) Bill is the natural next step. For the duty of disclosure on consumers it provides a single, clear and fair solution: abolition. Consumer groups, charities and leading industry associations have expressed their support. Hopefully the Bill will be enacted without delay.

\section{Peter Tyldesley}

Senior Research Fellow in Law, St Mary's University College Twickenham. The author will be publishing an extended paper on Carter v Boehm later this year (tyldesleyp@smuc.ac.uk). 